\title{
Response to "The Luminous Experience and the Scientific Method" by Oliver Nichelson
}

\author{
Carol Zaleski, Ph.D. \\ Smith College
}

ABSTRACT: Acknowledging the cultural shaping of near-death experiences makes possible a deeper and more sophisticated appreciation of their meaning and validity.

I would like to express my appreciation to Oliver Nichelson for his vigorous defense of near-death testimony. I find it puzzling, however, that Mr. Nichelson counts me among those academic theologians who would dismiss its claims.

Like Nichelson, I consider respect for individual testimony to be a fundamental, non-negotiable principle. I, too, am distressed by the tendency of academic theologians to treat reports of religious experience in a condescending or indiscriminately skeptical fashion.

Along with Kenneth Ring and other researchers, I have been deeply impressed by the transforming effects of near-death experiences. Following the pragmatic criteria devised by William James, who drew on the ancient biblical and pastoral tradition of judging a religious experience by its "fruits for life," I have come to the conclusion that there is indeed something real and revelatory going on here.

In my article in this Journal (1985) and in my book, Otherworld Journeys (1987), my greatest concern was to avoid the extremes of

Dr. Zaleski is Assistant Professor of Religion and Biblical Literature at Smith College. Requests for reprints should be addressed to her at the Department of Religion and Biblical Literature, 138 Elm St., Smith College, Northampton, MA 01063. 
skepticism and credulity in order to develop a more sophisticated appreciation and defense of near-death testimony. I believe that if we begin by acknowledging the cultural as well as physiological and psychological conditions that shape the near-death experience, we provide stronger grounds for defending its validity. In the long run, deliberate naivete about cultural conditioning can only make neardeath testimony vulnerable to the crudest forms of debunking.

Nichelson's misreading of my position probably derives from my use of terms like "mythic," "imaginative," and "symbolic." Nichelson's understanding of these terms is apparently quite different from mine. I use the term "myth" in a sense that has become standard among historians of religion such as Mircea Eliade and Joseph Campbell. Far from denoting falsehood or convenient illusion, "myth" is a name for symbolic narratives that shape our experience and bring us into contact with sacred realities that transcend us. Myths are stories to live by; and the mythic dimension of life is no less necessary in our scientific age today than it has been at any other time.

Many of us feel more comfortable in speaking about other people's myths than we do in acknowledging the mythic roots of our own thought. I agree with Nichelson that such lopsided awareness of mythic patterns in other people's experiences can have insidious effects. For that reason, I emphasized that "being of light" is no less a mythic expression than Krishna or Christ (Zaleski, 1985, 1987).

Similarly, scientists' descriptions of ultimate reality inevitably resort to mythic and symbolic language, though sometimes of a sadly impoverished kind. When we acknowledge the mythic, symbolic, and imaginative character of our own as well as other people's experiences, only then are we in a position to appreciate fully the power of myth, symbol, and imagination as mediators of truth.

Nowhere do I claim that near-death visions are merely "useful imaginings," or that encounters with God are inevitably illusory. What I do try to indicate is that the near-death experience is a symbolic encounter with one's own death, and that through this encounter one can come into contact with sacred realities. To say that this experience is mediated by the religious imagination and shaped by cultural forces is by no means to deny that it is an encounter with God.

While my perspective on near-death experiences is influenced by recent developments in academic theology and comparative history of religion, much of what I say about the symbolic nature of religious experience can be found in more traditional sources. The "direct experience" of which Nichelson wrote is precisely what so many religious thinkers have considered unavailable in this life. "Now we see through 
a glass darkly," wrote St. Paul. Now we must be content with a dark, enigmatic, symbolically shaped experience of God, until the eschaton makes possible a face-to-face vision.

If, as Christians believe, God willingly empties himself into human form, "the form of a slave," then is it not also possible that God willingly empties himself into the symbols that our culture makes available to us?

One small note: I do not recommend that near-death experiencers be quarantined! The passage to which Nichelson referred was a metaphorical treatment of a point made by William James in his Gifford Lectures, published in 1902 as The Varieties of Religious Experience. James wrote that "mystical states ... usually are, and have the right to be, absolutely authoritative over the individuals to whom they come"; but he qualifies this by saying "no authority emanates from them which should make it a duty for those who stand outside of them to accept their revelations uncritically" (James, 1958, pp. 323-324). To balance these two insights remains our greatest challenge as interpreters of the near-death experience.

\section{References}

James W. (1958). The varieties of religious experience. New York, NY: New American Library. [Originally published 1902.]

Zaleski, C. (1985). Evaluating near-death testimony: A challenge for theology. Anabiosis: The Journal of Near-Death Studies, 5(2), 17-52.

Zaleski, C. (1987). Otherworld Journeys. New York, NY: Oxford University Press. 